\title{
Functional performance and muscular strength in symptomatic female carriers of Duchenne muscular dystrophy
}

\author{
Desempenho funcional e força muscular em portadoras sintomáticas de distrofia \\ muscular de Duchenne
}

Thiago Henrique da SILVA1', Isabela Pessa ANEQUINI', Francis Meire FÁVERO², Mariana Callil VOOS', Acary Souza Bulle OLIVEIRA², Juliana Aparecida Rhein TELLES', Fátima Aparecida CAROMANO'

\begin{abstract}
Duchenne muscular dystrophy (DMD) usually affects men. However, women are also affected in rare instances. Approximately $8 \%$ of female DMD carriers have muscle weakness and cardiomyopathy. The early identification of functional and motor impairments can support clinical decision making. Objective: To investigate the motor and functional impairments of 10 female patients with dystrophinopathy diagnosed with clinical, pathological, genetic and immunohistochemical studies. Methods: A descriptive study of a sample of symptomatic female carriers of DMD mutations. The studied variables were muscular strength and functional performance. Results: The prevalence was 10/118 (8.4\%) symptomatic female carriers. Deletions were found in seven patients. The age of onset of symptoms in female carriers of DMD was quite variable. Pseudohypertrophy of calf muscles, muscular weakness, compensatory movements and longer timed performance on functional tasks were observed in most of the cases. Differently from males with DMD, seven female patients showed asymmetrical muscular weakness. The asymmetric presentation of muscle weakness was frequent and affected posture and functionality in some cases. The functional performance presents greater number of compensatory movements. Time of execution of activities was not a good biomarker of functionality for this population, because it does not change in the same proportion as the number of movement compensations. Conclusion: Clinical manifestation of asymmetrical muscle weakness and compensatory movements, or both can be found in female carriers of DMD mutations, which can adversely affect posture and functional performance of these patients.
\end{abstract}

Keywords: Duchenne muscular dystrophy; motor activity; muscle strength; female.

\section{RESUMO}

A distrofia muscular de Duchenne (DMD) geralmente afeta indivíduos do sexo masculino. No entanto, mulheres também são acometidas em casos raros. Aproximadamente $8 \%$ das portadoras de DMD têm fraqueza muscular ou cardiomiopatia. A identificação precoce das alterações funcionais e motoras pode alterar a tomada de decisão clínica. Objetivo: Investigar as deficiências motoras e funcionais de 10 pacientes do sexo feminino com distrofinopatia diagnosticada por estudos clínicos, patológicos, genéticos e imuno-histoquímicos. Método: Estudo descritivo de uma amostra de portadoras sintomáticas de mutações DMD. As variáveis estudadas foram força muscular e desempenho funcional. Resultados: A prevalência foi de 10/118 (8,4\%) de portadoras sintomáticas de DMD. Foram encontradas deleções em sete pacientes. A idade de início dos sintomas em portadoras de DMD foi variável. Pseudo-hipertrofia de panturrilhas, movimentos compensatórios, fraqueza muscular e aumento no tempo de execução de tarefas funcionais foram observados na maioria dos casos. Diferentemente dos homens com DMD, sete pacientes apresentaram fraqueza muscular assimétrica. A apresentação assimétrica da fraqueza muscular foi frequente, podendo afetar a postura e a funcionalidade. 0 desempenho funcional geralmente apresenta aumento no número de movimentos compensatórios. Não podemos sempre considerar o tempo como um bom marcador de funcionalidade para essa população, uma vez que não muda na mesma proporção que o número de compensações em todas essas pacientes. Conclusão: Fraqueza muscular assimétrica e movimentos compensatórios, ou ambos, podem ser encontrados em portadoras sintomáticas de DMD, o que pode afetar a postura e a funcionalidade dessas pacientes.

Palavras-chave: distrofia muscular de Duchenne; atividade motora; força muscular; feminino.

\footnotetext{
1 Universidade de São Paulo, Faculdade de Medicina, Departamento de Fisioterapia, Fonoaudiologia e Terapia Ocupacional, São Paulo SP, Brazil. Universidade Federal de São Paulo, Escola Paulista de Medicina, Departamento de Neurologia/Neurocirurgia, São Paulo SP, Brazil.

Thiago Henrique da SILVA (iD https://orcid.org/0000-0002-3502-6687; Isabela Pessa ANEQUINI (iD https://orcid.org/0000-0003-0906-8338; Francis Meire FÁVERO (iD https://orcid.org/0000-0001-8063-8167; Mariana Callil VOOS (iD) https://orcid.org/0000-0001-6252-7287; Acary Souza Bulle OLIVEIRA (iD) https://orcid.org/0000-0002-6986-4937; Juliana Aparecida Rhein TELLES iD https://orcid.org/0000-0001-8460-8133; Fátima Aparecida CAROMANO (iD https://orcid.org/0000-0003-4235-2138

Correspondence: Fátima Caromano; Rua Cipotânea, 51; Cidade Universitária; 05360-160 São Paulo SP, Brazil; E-mail: caromano@usp.br Conflict of interest: There is no conflict of interest to declare.

Received on September 13, 2018; Received in its final form on August 17, 2019; Accepted on October 21, 2019.
} 
Female carriers of Duchenne muscular dystrophy (DMD) could develop symptoms of the disease and are classified as "symptomatic" or "manifesting". Usually, the clinical presentation is milder than in male carriers, including asymmetric muscle weakness with proximal predominance and onset age variable ${ }^{1,2}$. Almost $8 \%$ of DMD female carriers present some symptom, including some level of muscular weakness with or without cardiomyopathy ${ }^{3,4}$. Therefore, we use the term symptomatic female carriers when relating to symptomatic carriers of DMD mutations, in which DMD refers to the gene and not to the disease.

The early stages of motor function decline in DMD are already well known, including loss of walking ability, which occurs on average at nine years of age in men ${ }^{5}$. However, in symptomatic female carriers, that information is poorly described in the literature, as well as the analysis of the performance in functional tasks. Rather, several studies characterize the cardiac symptomatology in female carriers of $\mathrm{DMD}^{3,4,6}$, and few report muscle disorders ${ }^{7,8}$.

Studies of symptomatic female carriers with DMD mutations have been rarely performed in Brazil ${ }^{9,10}$. The present research differs from the others due to our main purpose, which is to describe the performance in functional tasks, and the muscular strength of these patients. Identification of functional changes in neuromuscular disorders is important to provide grounds for appropriate clinical decision. Epidemiological and clinical studies of these patients can clarify this issue.

\section{METHODS}

Descriptive study of a sample of symptomatic female carriers of DMD mutations, confirmed by molecular diagnostics at the Physiotherapy Service of the Human Genome Research Center, Universidade de São Paulo, from June 2008 to August 2015. Genetic counselling service recommended genetic testing of mothers of all individuals affected by DMD; consequently, the carriers were identified. Furthermore, some patients under examination for other neuromuscular diseases were also identified as symptomatic female carriers of DMD mutations. Investigations had included full medical history, as well as neurological and cardiological examination.

The classification of patients as symptomatic carriers was based on the presence of regular muscle cramps and pains, affecting or not daily life activities, muscle weakness in at least one muscle group and cardiomyopathy clearly described or detected by echocardiogram. The screening for mutations in the dystrophin gene was done with multiplex ligation-dependent probe amplification (MLPA), multiplex polymerase chain reaction (PCR) and next-generation sequencing (NGS). Symptomatic female carriers of DMD mutations were submitted to muscle biopsy and histomorphological study. Furthermore, muscle protein analyses were performed by immunohistochemistry, which evidenced dystrophic pattern.

All charts $(\mathrm{n}=118)$ from DMD female carriers were analyzed. Thereafter, 10 DMD female carriers showing clinical symptoms were detected. Data collected included muscular strength, measured by the Medical Research Council (MRC) scale, and clinical staging, evaluated using Vignos Scale and Functional Evaluation Scale for DMD. Muscle strength of the upper limbs was performed on the flexors, extensors and abductors of the shoulder; flexors and extensors of the elbow; and flexors and extensors of the wrist. In the lower limbs, the flexors, extensors and adductors of the hip, flexors and extensors of the knee and dorsiflexors and flexors of the ankle were evaluated.

After the clinical evaluation of muscle strength, the percentage was calculated with the MRC index (sum of the score divided by the number of muscles tested, considering body segments). The criterion for determining muscle strength asymmetry considered different findings between sides of the body midline. Functional Evaluation Scale for DMD (FES-DMD) was performed using a systematic observation, with measurement of task execution time and qualitative analysis of movements. This scale has four domains: sitting on and standing from the chair ${ }^{11}$; sitting on and standing from the ground ${ }^{12}$; going up and down the stairs ${ }^{13}$; and gait $^{14}$. In addition, postural evaluation was performed in orthostatic posture with the posture grid (Carci') and direct observation and record of disorders. All data were collected by qualified Neuromuscular Physical Therapists, who were part of research.

This study was approved by the Research Ethics Committee of Universidade Federal de São Paulo.

\section{RESULTS}

In our sample, prevalence was 10/118 (8.4\%) of symptomatic female carriers. Age ranged from 8 to 62 years, demonstrating an important heterogeneity. The onset age of manifesting symptoms varied from 1 to 50 years. Vignos classification score ranged from 0 to 4 . Functional general data are listed in Table 1.

Deletions were found in seven patients. One case of duplication and two cases of point mutation were found. The most used method was MLPA. PCR confirmed the diagnosis of two patients, and NGS was used in three patients of the sample.

Pseudohypertrophy of calf muscles, compensatory movements and longer timed performance on functional tasks (sitting on and rising from a chair and from the ground, walking and climbing up and down steps) were observed in seven cases. The main complaints presented by the patients were functional performance and pain (Table 2). 
Muscular weakness was detected with MRC tests in all cases. Differently from males with DMD, seven patients showed asymmetrical muscular weakness, which is very diverse (Table 3).

Younger patients showed less severe impairments than older ones. The loss of muscle strength occurred slowly and with little variation, although the intensity for patient number 4 has varied significantly during the period. Research on muscle strength index showed that patients 1, 2 and 3 have a lower motor impairment than the others. They are the youngest individuals in the sample, with all being younger than 20 years old at the time of evaluation (Table 4).

Table 1. General patient information.

\begin{tabular}{|c|c|c|c|c|c|c|c|c|}
\hline Patient & Age & $\begin{array}{l}\text { Onset of } \\
\text { symptoms } \\
\text { (age) }\end{array}$ & $\begin{array}{l}\text { Diagnosis } \\
\text { (age) }\end{array}$ & Funcional performance & $\begin{array}{l}\text { Vignos } \\
\text { scale }\end{array}$ & Muscle strength & $\begin{array}{l}\text { Postural } \\
\text { changes }\end{array}$ & $\begin{array}{l}\text { Follow-up } \\
\text { period (number } \\
\text { of evaluations } \\
\text { over the years) }\end{array}$ \\
\hline 1 & 8 & 7 & 8 & $\begin{array}{l}\text { Walks and climbs stairs with } \\
\text { discrete compensatory movements }\end{array}$ & $P$ & $\begin{array}{l}\text { Symmetrical proximal } \\
\text { muscle weakness }\end{array}$ & $\begin{array}{l}\text { Without } \\
\text { changes }\end{array}$ & 1 \\
\hline 2 & 20 & $\mathrm{NI}$ & 20 & $\begin{array}{l}\text { Walks and climbs stairs with } \\
\text { discrete compensatory movements }\end{array}$ & $P$ & $\begin{array}{l}\text { Asymmetrical } \\
\text { proximal muscle } \\
\text { weakness }\end{array}$ & $\begin{array}{l}\text { Without } \\
\text { changes }\end{array}$ & 1 \\
\hline 3 & 20 & 1 & 17 & $\begin{array}{l}\text { Walks and climbs stairs with } \\
\text { compensatory movements }\end{array}$ & 01 & $\begin{array}{l}\text { Asymmetrical } \\
\text { proximal muscle } \\
\text { weakness }\end{array}$ & $\begin{array}{l}\text { Left thoracic } \\
\text { scoliosis }\end{array}$ & $\begin{array}{c}2 \text { evaluations in } \\
3 \text { years }\end{array}$ \\
\hline 4 & 22 & 3 & 14 & $\begin{array}{c}\text { Standing from the chair performing } \\
\text { Gowers. Walks and climbs stairs } \\
\text { with compensations. }\end{array}$ & 02 & $\begin{array}{l}\text { Asymmetric global } \\
\text { muscle weakness }\end{array}$ & $\begin{array}{l}\text { Lumbar } \\
\text { hyperlordosis, } \\
\text { globular } \\
\text { abdomen }\end{array}$ & $\begin{array}{l}4 \text { evaluations in } \\
5 \text { years }\end{array}$ \\
\hline 5 & 30 & 22 & 30 & $\begin{array}{l}\text { Walks and climbs stairs with } \\
\text { compensations. Standing from the } \\
\text { floor performing Gowers }\end{array}$ & 01 & $\begin{array}{l}\text { Asymmetrical } \\
\text { proximal muscle } \\
\text { weakness }\end{array}$ & $\begin{array}{l}\text { Without } \\
\text { changes }\end{array}$ & 1 \\
\hline 6 & 34 & 25 & 34 & $\begin{array}{l}\text { Standing from the chair and the } \\
\text { floor, walks and climbs stairs with } \\
\text { compensatory movements. }\end{array}$ & 02 & $\begin{array}{l}\text { Asymmetrical } \\
\text { proximal muscle } \\
\text { weakness }\end{array}$ & $\begin{array}{l}\text { Lumbar } \\
\text { hyperlordosis, } \\
\text { protruding } \\
\text { shoulders }\end{array}$ & (n) \\
\hline 7 & 37 & 20 & 41 & $\begin{array}{l}\text { Can't go up stairs. Depends on help } \\
\text { to standing from the floor and the } \\
\text { chair. Walks with Canadian crutch. }\end{array}$ & 05 & $\begin{array}{l}\text { Asymmetric global } \\
\text { muscle weakness }\end{array}$ & $\begin{array}{l}\text { Lumbar } \\
\text { hyperlordosis, } \\
\text { globular } \\
\text { abdomen }\end{array}$ & $\begin{array}{l}6 \text { evaluations in } \\
6 \text { years }\end{array}$ \\
\hline 8 & 43 & $\mathrm{NI}$ & 40 & $\begin{array}{c}\text { Climbs stairs with compensatory } \\
\text { movements }\end{array}$ & 02 & $\begin{array}{l}\text { Asymmetric global } \\
\text { muscle weakness }\end{array}$ & $\begin{array}{l}\text { Lumbar } \\
\text { hyperlordosis, } \\
\text { thoracic } \\
\text { kyphosis }\end{array}$ & 1 \\
\hline 9 & 61 & 37 & 57 & $\begin{array}{c}\text { Walks with a cane. Stands from } \\
\text { the floor with compensatory } \\
\text { movements }\end{array}$ & 02 & $\begin{array}{l}\text { Symmetrical global } \\
\text { muscle weakness }\end{array}$ & $\begin{array}{c}\text { Lumbar } \\
\text { hyperlordosis, } \\
\text { thoracic } \\
\text { kyphosis }\end{array}$ & $\begin{array}{c}3 \text { evaluations in } \\
4 \text { years }\end{array}$ \\
\hline 10 & 63 & 50 & 54 & $\begin{array}{l}\text { Walks and stands from the floor } \\
\text { with compensatory movements }\end{array}$ & 01 & $\begin{array}{l}\text { Asymmetric global } \\
\text { muscle weakness }\end{array}$ & $\begin{array}{l}\text { Lumbar } \\
\text { hyperlordosis, } \\
\text { left thoracic } \\
\text { scoliosis }\end{array}$ & $\begin{array}{c}5 \text { evaluations in } \\
7 \text { years }\end{array}$ \\
\hline
\end{tabular}

NI: no information; P: preclinical.

Table 2. Clinical condition and the main complaints presented by the patients.

\begin{tabular}{|c|c|c|c|c|c|c|c|}
\hline Patient & Pseudohypertrophy & Complaints & Pain & Falls & Cramps & Fatigue & DFP \\
\hline 1 & No & No & No & No & No & No & No \\
\hline 2 & Right calf & No & No & No & No & Yes & No \\
\hline 3 & Calves & Posture & Yes & No & No & Yes & No \\
\hline 4 & Calves & $\mathrm{FP}$ & Yes & Frequent & No & Yes & Yes \\
\hline 5 & No & Pain / Fatigue & Yes & No & Yes & Yes & No \\
\hline 6 & Right calf & FP & Yes & No & No & No & Yes \\
\hline 7 & No & FP & Yes & Sporadic & Yes & Yes & Yes \\
\hline 8 & Calves & Pain & Yes & No & No & Yes & No \\
\hline 9 & Calves & Pain / Tremors & Yes & Sporadic & No & No & No \\
\hline 10 & Calves & Pain / Fatigue & Yes & Sporadic & No & Yes & No \\
\hline
\end{tabular}

$\mathrm{NI}$ : no information; FP: functional performance; DFP: decline in functional performance. 
The FES-DMD systematized evaluation and allowed to compare these findings in symptomatic carriers with males affected by DMD. The performance in functional tasks presented a greater number of compensatory movements and longer task execution time, progressively. Thus, it was observed that older age patients performed worse in the tasks tested in this sample, as previously demonstrated in male patients.

\section{DISCUSSION}

The prevalence of symptomatic carriers found in our research is similar to other studies ${ }^{3,4}$. Samples with heterogeneous age and diversity in early symptoms are also evident in different studies ${ }^{8,15,16}$ and suggest that the early onset of symptoms is related to the severity of the clinical condition $^{1,2}$. It was possible to observe two cases of patients with onset of symptoms in early childhood in our sample. Patients 3 and 4 were less than four years old when symptoms first manifested, and both were ambulatory by the time they were twenty. Our sample size is not large but, considering the rarity of the situation and the scarcity of similar publications, this study raises awareness about this uncommon phenotype within the spectrum of dystrophinopathies.
In accordance with our findings, a previous study suggests that age is related to impaired motor and functional symptoms in these patients ${ }^{16}$. Our results show that among patients aged over 20 years it was possible to observe a greater impairment of muscle strength and functionality. There was also a consequent decline in subsequent evaluations, even if discrete in some cases. Other studies show a severe impairment in symptomatic patients of older ages ${ }^{3,4}$. The progression of the disease is determinant on myocardial dysfunction, which is supported by the findings of Grain et al. $^{17}$, that showed a relation between more advanced age and cardiac alterations ${ }^{17}$. Our research does not present cardiac data for the symptomatic carriers of DMD mutations; the focus is on motor impairments, and the individuals studied do not present isolated cardiac symptoms.

Pain and muscle weakness, in addition to cramps, are symptoms previously described in these patients ${ }^{7,15}$. In our sample, the complaints are probably related to the progressive decline of functional performance, which is due to muscle weakness. This decline causes impacts on activities of daily living (ADL), that can affect simple movements, such as walking, lifting objects and going up and down the stairs.

According to our findings, clinical evaluation with MRC was a reliable item for assessing muscle strength in these patients. In recent research, asymmetry was observed mainly

Table 3. Asymmetrical muscle weakness and muscle groups.

\begin{tabular}{lr}
\hline Patient & Muscle Groups \\
\hline 1 & Symmetrical Global Weakness \\
2 & Hip Flexors L \\
3 & Hip Extensors R \\
4 & Shoulder \\
5 & Elbow Flexors L, Elbow Extensors L, Hip Flexors L \\
6 & Shoulder Abductors R, Elbow Flexors R, Hip Flexors R, Hip Abdctors R \\
7 & Shoulder Abductors L, Knee Extensors L \\
8 & Symmetrical Global Weakness \\
9 & Hip Extensors L, Hip Adductors R, Ankle Dorsiflexors R \\
\hline
\end{tabular}

L: left; R: right.

Table 4. Index of muscular strength (\%) in the initial and final assessments of patients.

\begin{tabular}{|c|c|c|c|c|c|c|c|c|}
\hline \multirow[b]{2}{*}{ PATIENT } & \multicolumn{2}{|c|}{ Proximal Upper Extremity } & \multicolumn{2}{|c|}{ Distal Upper Extremity } & \multicolumn{2}{|c|}{ Proximal Lower Extremity } & \multicolumn{2}{|c|}{ Distal Lower Extremity } \\
\hline & $\begin{array}{c}\text { Initial } \\
\text { Assessment }\end{array}$ & $\begin{array}{c}\text { Final } \\
\text { Assessment }\end{array}$ & $\begin{array}{c}\text { Initial } \\
\text { Assessment }\end{array}$ & $\begin{array}{c}\text { Final } \\
\text { Assessment }\end{array}$ & $\begin{array}{c}\text { Initial } \\
\text { Assessment }\end{array}$ & $\begin{array}{c}\text { Final } \\
\text { Assessment }\end{array}$ & $\begin{array}{c}\text { Initial } \\
\text { Assessment }\end{array}$ & $\begin{array}{c}\text { Final } \\
\text { Assessment }\end{array}$ \\
\hline 1 & $86.7 \%$ & OE & $97.5 \%$ & OE & $93.3 \%$ & $\mathrm{OE}$ & $100 \%$ & OE \\
\hline 2 & $96.7 \%$ & $\mathrm{OE}$ & $100 \%$ & OE & $96.7 \%$ & OE & $100 \%$ & OE \\
\hline 3 & $100 \%$ & $100 \%$ & $100 \%$ & $100 \%$ & $100 \%$ & $96.7 \%$ & $100 \%$ & $100 \%$ \\
\hline 4 & $86.6 \%$ & $60.2 \%$ & $95.0 \%$ & $75.5 \%$ & $86.6 \%$ & $63.3 \%$ & $86.6 \%$ & $65.3 \%$ \\
\hline 5 & $80.0 \%$ & OE & $95.0 \%$ & OE & $90.0 \%$ & OE & $90.0 \%$ & OE \\
\hline 6 & $70.0 \%$ & OE & $95.0 \%$ & OE & $56.7 \%$ & $\mathrm{OE}$ & $82.5 \%$ & OE \\
\hline 7 & $46.6 \%$ & $43.3 \%$ & $50.0 \%$ & $65.0 \%$ & $65.0 \%$ & $60.0 \%$ & $85.0 \%$ & $75.0 \%$ \\
\hline 8 & $76.6 \%$ & OE & $80.0 \%$ & $\mathrm{OE}$ & $73.3 \%$ & OE & $82.5 \%$ & OE \\
\hline 9 & $73.3 \%$ & $73.3 \%$ & $100 \%$ & $90.0 \%$ & $73.6 \%$ & $73.3 \%$ & $65.0 \%$ & $70.0 \%$ \\
\hline 10 & $86.6 \%$ & $80.0 \%$ & $100 \%$ & $85.0 \%$ & $80.0 \%$ & $80.0 \%$ & $90.5 \%$ & $77.5 \%$ \\
\hline
\end{tabular}

OE: one-off evaluation. 
in the gluteus and thigh adductor muscles, as evaluated with diagnostic imaging ${ }^{8}$. Oliveira et al. ${ }^{18}$ evaluated 13 muscular biopsies of possible DMD carriers and, in six cases, dystrophin-positive and dystrophin-deficient mosaics were identified, which allowed the diagnostic confirmation of these carriers without discriminating functional dominance or muscle strength in the hemiforms ${ }^{18}$.

The progression of DMD results in the development of compensatory movements to supply muscle weakness and the demand for ADLs ${ }^{19}$. They were observed during the performance of functional activities in the present study. No data were found reporting compensatory movements in symptomatic female carriers of DMD mutations for comparative purposes. Although the number of compensatory movements had been increasing throughout the evaluations, the time for performing the tasks did not increase in the same proportion. Many of the compensations performed by our study sample are the same as those often seen in males with $\mathrm{DMD}^{11,13,14}$, as described in Table 5.

Changes in muscle strength and functional performance did not have a significant impact on the clinical staging of patients in our sample, with one exception. Vignos scale score showed a significant change in patient 7 . She presented the initial symptoms at 20. In the initial evaluation, the score was 3 on the Vignos scale and progressed to 4 after two years and to 5 after one more year, though it was maintained in the following two years. In this case, there was an important functional alteration. Mercier et al. ${ }^{20}$ presented in a sample of 26 symptomatic carriers that seven patients became wheelchair users (two cases before age 15 years) ${ }^{20}$. In our sample, except for the patient mentioned above, there was no significant impact on the evaluation of clinical staging over the years.
In other studies, deletions are the predominant mutations, as found by Juan-Mateu et al., who evaluated 40 carriers, of which 20 deletions, five duplications and three point mutations were identified ${ }^{21}$. Genetic data cannot be correlated with motor status, at first due to the reduced number of participants in most studies, unlike in male subjects with DMD.

The relevance of the use of functional scales is evident in these patients. Moreover, our study is the first one to use the Vignos scale to categorize the clinical staging of symptomatic female carriers, and the first to describe the motor performance of these patients with an evaluation scale, comparing the findings with the clinical condition of males.

One limitation of this study was the lack of determination of the X chromosome inactivation pattern. Nonetheless, this study did not compare motor function with genetic, cardiac and histopathologic data, which would provide a connection between genotype and phenotype and, consequently, enable us to understand the cause of the manifesting DMD status in this sample.

In conclusion, the age of which symptoms manifest in female carriers of DMD mutations is quite variable. Younger patients presented less muscular involvement with better functional performance, just like it had occurred in men. The asymmetric presentation of muscle weakness is frequent and can affect posture and functionality, with greater number of compensatory movements, progressively. We cannot consider time as a good biomarker of functionality for symptomatic female carriers of DMD mutations, because it does not change in the same proportion as the number of compensatory movements in all symptomatic carriers. Functional scales used to evaluate males with DMD could also be used in symptomatic carriers.

Table 5. Comparison of compensatory movements between male and female DMD carriers.

\begin{tabular}{|c|c|c|c|}
\hline $\begin{array}{l}\text { Domain } \\
\text { FES-DMD }\end{array}$ & Task & $\begin{array}{l}\text { Compensatory movements } \\
\text { male carriers of } \mathrm{DMD}^{* *}\end{array}$ & $\begin{array}{l}\text { Symptomatic female } \\
\text { carriers of DMD mutations }\end{array}$ \\
\hline D1 & $\begin{array}{l}\text { Sitting and standing } \\
\text { from the chair }\end{array}$ & $\begin{array}{l}\text { - } \quad \text { Hyperextension of the knee } \\
\text { - } \quad \text { Hip rotation } \\
\text { - } \quad \text { Trunk rotation / inclination } \\
\text { - } \quad \text { Cervical spine hyperextension / rotation / } \\
\text { inclination** }\end{array}$ & $\begin{array}{l}\text { - Upper limbs Support } \\
\text { - Increased base of support }\end{array}$ \\
\hline D2 & Gait & $\begin{array}{l}\text { - } \quad \text { Ankle plantar flexion } \\
\text { - } \quad \text { Inedial hip rotation } \\
\text { - } \quad \text { Head / trunk anteriorization** }\end{array}$ & $\begin{array}{l}\text { - } \quad \text { Pelvic tilt } \\
\text { - } \quad \text { Ankle plantar flexion } \\
\text { Hyperextension of the knee }\end{array}$ \\
\hline D3 & $\begin{array}{l}\text { Climbing up and } \\
\text { going down the } \\
\text { stairs }\end{array}$ & $\begin{array}{l}\text { - Increased base of support } \\
\text { - } \quad \text { Lumbar hyperlordosis } \\
\text { - } \quad \text { Ankle plantar flexion } \\
\text { - Trunk inclination } \\
\text { - } \quad \text { Pelvic tilt** }\end{array}$ & $\begin{array}{ll}\text { - } & \text { Pelvic tilt } \\
\text { - } & \text { Trunk inclination } \\
\text { - } & \text { Hyperextension of the knee } \\
\text { - } & \text { Upper limbs support }\end{array}$ \\
\hline D4 & $\begin{array}{l}\text { Sitting down on / } \\
\text { rising from the floor }\end{array}$ & - Gower's sign** & - Upper limbs support \\
\hline
\end{tabular}

D1: Domain 1; D2: Domain 2; D3: Domain 3; D4: Domain 4; **as described by the following authors: Hukuda, 201411; Martini, $2015^{19}$; Escórcio, $2011^{12}$. 
1. Moser H, Emery AE. The manifesting carrier in Duchenne muscular dystrophy. Clin Genet. 1974;5(4):271-84. https://doi. org/10.1111/j.1399-0004.1974.tb01694.x

2. Norman A, Harper P. A survey of manifesting carriers of Duchenne and Becker muscular dystrophy in Wales. Clin Genet. 1989 Jul;36(1):31-7. https://doi.org/10.1111/j.1399-0004.1989.tb03363.x

3. Kamakura K, Kawai M, Arahata K, Koizumi H, Watanabe K, Sugita H. A manifesting carrier of Duchenne muscular dystrophy with severe myocardial symptoms. J Neurol. 1990 Dec;237(8):483-5. https://doi. org/10.1007/bf00314767

4. Hoogerwaard EM, van der Wouw PA, Wilde AA, Bakker E, Ippel PF, Oosterwijk JC, et al. Cardiac involvement in carriers of Duchenne and Becker muscular dystrophy. Neuromuscul Disord. 1999 Jul;9(5):34751. https://doi.org/10.1016/s0960-8966(99)00018-8

5. Sussman M. Duchenne muscular dystrophy. J Am Acad Orthop Surg. 2002 Mar-Apr;10(2):138-51.https://doi.org/10.5435/00124635200203000-00009

6. Adachi K, Hashiguchi S, Saito M, Kashiwagi S, Miyazaki T, Kawai $\mathrm{H}$, et al. Detection and management of cardiomyopathy in female dystrophinopathy carriers. J Neurol Sci. 2018 Mar;386:74-80. https:// doi.org/10.1016/j.jns.2017.12.024

7. Hoogerwaard EM, Bakker E, Ippel PF, OosterwijkJC, Majoor-Krakauer DF, Leschot NJ, et al. Signs and symptoms of Duchenne muscular dystrophy and Becker muscular dystrophy among carriers in The Netherlands: a cohort study. Lancet. 1999 Jun;353(9170):2116-9. https://doi.org/10.1016/s0140-6736(98)10028-4

8. Soltanzadeh P, Friez MJ, Dunn D, von Niederhausern A, Gurvich $\mathrm{OL}$, Swoboda KJ, et al. Clinical and genetic characterization of manifesting carriers of DMD mutations. Neuromuscul Disord. 2010 Aug;20(8):499-504. https://doi.org/10.1016/j.nmd.2010.05.010

9. Werneck LC, Lemos SML, Magdalena N. Distrofia muscular de Duchenne em menina com translocação cromossômica. Arq Neuropsiquiatr. 1988;46(4):401-405. http://dx.doi.org/10.1590/ S0004-282X1988000400012

10. Cotta A, Paim JF, Carvalho E, Navarro MM, ValicekJ, da-CunhaJunior AL, et al. Phenotypic Variability of Dystrophinopathy Symptomatic Female Carriers. Can J Neurol Sci. 2017 May;44(3):30410. https://doi.org/10.1017/cjn.2016.448

11. Hukuda ME, Escorcio R, Fernandes LA, de Carvalho EV, Caromano FA. Evaluation scale development, reliability for sitting and standing from the chair for Duchenne muscular dystrophy. J Mot Behav. 2013;45(2):117-26. https://doi.org/10.1080/00222895.2012.760513

12. Escorcio R, Caromano FA, Hukuda ME, Fernandes LA. Development of an evaluation scale for sitting and standing from the ground for children with Duchenne muscular dystrophy.J Mot Behav. 2011;43(1):31-6. https://doi.org/10.1080/00222895.2010.530306
13. Fernandes LA, Caromano FA, Hukuda ME, Escorcio R, Carvalho EV. Elaboration and reliability of functional evaluation on going up and downstairs scale for Duchenne Muscular Dystrophy. Rev Bras Fisioter. 2010 Nov/Dec;14(6):518-26. http://dx.doi.org/10.1590/ S1413-35552010000600011

14. de Carvalho EV, Hukuda ME, Escorcio R, Voos MC, Caromano FA. Development and Reliability of the Functional Evaluation Scale for Duchenne Muscular Dystrophy, Gait Domain: A Pilot Study. Physiother Res Int. 2015 Sep;20(3):135-46. https://doi. org/10.1002/pri.1605

15. Song TJ, Lee KA, Kang SW, Cho H, Choi YC. Three cases of manifesting female carriers in patients with Duchenne muscular dystrophy. Yonsei Med J 2011 Jan;52(1):192-5. https://doi.org/10.3349/ ymj.2011.52.1.192

16. Brioschi S, Gualandi F, Scotton C, Armaroli A, Bovolenta M, Falzarano MS, et al. Genetic characterization in symptomatic female DMD carriers: lack of relationship between $X$-inactivation, transcriptional DMD allele balancing and phenotype. BMC Med Genet. 2012 Aug;13:73. https://doi. org/10.1186/1471-2350-13-73

17. Grain L, Cortina-Borja M, Forfar C, Hilton-Jones D, Hopkin J, Burch M. Cardiac abnormalities and skeletal muscle weakness in carriers of Duchenne and Becker muscular dystrophies and controls. Neuromuscul Disord. 2001 Mar;11(2):186-91. https://doi. org/10.1016/s0960-8966(00)00185-1

18. Oliveira ASB, Gabbai AA, Schmidt B, Kiyomoto BH, Lima JGC, Minetti $C$, et al. Carrier detection of Duchenne and Becker muscular dystrophy using muscle dystrophin immunohistochemistry. Arq Neuropsiquiatr. 1992 Dec;50(4):478-85. http://dx.doi.org/10.1590/ S0004-282X1992000400010

19. Martini J, Voos MC, Hukuda ME, Resende MB, Caromano FA. Compensatory movements during functional activities in ambulatory children with Duchenne muscular dystrophy. Arq Neuropsiquiatr. 2014 Jan;72(1):5-11. https://doi. org/10.1590/0004-282X20130196

20. Mercier S, Toutain A, Toussaint A, Raynaud M, de Barace C, Marcorelles P, et al. Genetic and clinical specificity of 26 symptomatic carriers for dystrophinopathies at pediatric age. Eur J Hum Genet. 2013 Aug;21(8):855-63. https://doi.org/10.1038/ ejhg.2012.269

21. Juan-Mateu J, Rodríguez MJ, Nascimento A, Jiménez-Mallebrera C, González-Quereda L, Rivas E, et al. Prognostic value of $X$-chromosome inactivation in symptomatic female carriers of dystrophinopathy. Orphanet J Rare Dis. 2012;7(1):82. https://doi. org/10.1186/1750-1172-7-82 